\title{
Philosophy of Science in Islamic Thought Perspective
}

\author{
Marlian Arif Nasution \\ Universitas Islam Negeri Sumatera Utara \\ arif.nasution@gmail.com
}

\begin{abstract}
Tracing a starting point that is very important from the traditional Islamic sciences, modern Western science was developed such that it adopts a philosophical footing. Unlike modern Islamic science, the philosophical footing is to be distinguished from the philosophical foundation of Islamic science. Indeed, Islamic science main concern is closely related to the basic philosophy of science issues is growing and is recognized today, including science paradigms and methodologies developed in the modern world that is more influenced by the thinking paradigm of the modern secular Western philosophy. This implies bias in epistemology and axiology between science and moral paradigm developed in Islam. In the practical level of science that was developed to be dried from a religious touch, these conditions afflict various disciplines of knowledge that Muslims studied. Therefore, Muslims increasingly need to differentiate between Islam and science that is not Islamic. Today, not many intellectual issues are more important to the contemporary Islamic world beyond the relationship between Islam and modern science.
\end{abstract}

Keywords: Islamic philosophy, Islamic Thought, and science

Abstrak. Menelusri titik awal ilmu-ilmu Islam tradisional, ilmu pengetahuan Barat modern yang dikembangkan sedemikian rupa, sehingga mengadopsi pijakan filosofis. Berbeda dengan ilmu pengetahuan Islam modern, landasan filosofis harus dibedakan dari landasan filosofis ilmu Islam. Memang perhatian utama ilmu Islam sangat erat kaitannya dengan dasar pemikiran filsafat ilmu yang berkembang, termasuk paradigma ilmu dan metodologi yang berkembang di dunia modern dipengaruhi oleh paradigma pemikiran 
filsafat Barat modern. Implikasi bias dalam epistemologi dan aksiologi antara sains dan paradigma moral yang berkembang dalam Islam. Dalam tataran praktis ilmu yang dikembangkan keringkan dari sentuhan agama, hal tersebut terjadi dalam disiplin ilmu yang dipelajari umat Islam. Untuk itu, umat Islam perlu membedakan antara Islam dan sains yang bukan Islam. Saat ini, banyak masalah bagi dunia Islam kontemporer di luar hubungan antara Islam dan sains modern.

\section{Introduction}

7 oday the world is witnessing the phenomenal and spectacular development of Western civilization. Western civilization is currently the pinnacle of human civilization that has been achieved throughout history. Science and advanced technology that has been achieved by the West can meet human needs. Since the Industrial Revolution in 16th century England and the French revolution (1789), the West has moved forward like an arrow missing its bow after the Middle Ages left behind in the dark ages (Iqbal, $2011,1)$. The development of science is inseparable from technological, political, economic, social, and philosophical developments in society. The development of science in the $2 \mathrm{O}^{\text {th }}$ century. History recorded a big change in this 2oth century. All these changes evolved from the philosophy adopted by people almost worldwide in the previous periods (Tafsir, 2009, 257).

The philosophy of rationalism in the period before the $20^{\text {th }}$ century has influenced the human soul to become a God of reason. Between human hearts and minds that did not meet at that time has created a multidimensional crisis. In this century, there was a tremendous crisis resulting from science and technology developed by human beings with lesser ratios, nuclear disasters, world wars, famine, disease spread, and others. However, it is not uncommon for science and technology discoveries to provide solutions to these crises (Tafsir, 2009, 257). When the connection between the heart and the mind has been severed, humans will realize that the ideal life formula question will never be answered. The attitude results in a tendency to set aside all values and norms based on religion. They also deny the existence of an afterlife. Humans are alienated without limit and losing orientation. A mechanistic situation drives humans to create himself and loses time to reflect on his life and the universe (Tafsir, 2009, 26o).

Two forces influence world civilization, namely religion, and philosophy. These two great powers vie for influence over mankind with promises of safety and progress. Philosophy has spawned a variety of science, ranging from the social sciences-humanities until the natural sciences. However, in its history, between the two (religion and philosophy), there have often been problems so 
that they are not united (integration) to solve complex human problems (Tafsir, 20o9, 7). The problems of religion and science, in their history, can be traced back to the Middle Ages, that is, from the 2nd century AD If we count the birth of Plotinus (204 AD) (Syamsuddin, 2012, 49-5o). In the early Middle Ages, there was a competition between science (which is a legacy of Greek philosophy) and religion (Christianity), which attempted to form theological formulations (Mayer, 1950, 347-348). Each religion and science feel to have a higher truth. So, Christianity feels the need to formulate its theological formulation; meanwhile, science (as a legacy of Greek philosophy) has been formulated long before, estimated since the 6th century (Rahman, 2013, 201). In the middle ages, the Church (Christianity) began to dominate the truth of science. All the sciences that developed at that time, such as philosophy, natural sciences, history, politics, had to submit to revelation because everything was considered final because it came from God. According to Augustine (354-430 AD) (Hadiwijono, 1980, 79-82). There is a Church doctrine that every scientific activity is a deviant activity and is nothing more than a wasteful activity. All activities empiric required when supporting the truth of God's revelation (Syamsuddin, 2012, 51).

The Church's doctrine of science continued to use violence against scientists who disagreed. This was as happened to a female scientist named Hypatia, was massacred by Christian zealots in $\mathrm{AD}$ 415. Not long after the killings, the Alexandrian library, known for its greatness, was burned to the ground with all of its contents. Strangely again, Archbishop of Alexandria Cyril, who commanded all this, was considered a saint by being given the title Saint (Madjid, 200o, xxxi-xxxii). Not only did it stop there, in $529 \mathrm{AD}$, but the emperor Justinian also ordered to ban and close scientific schools, including Plato's Academy, which had been founded in 387 BC (Rahman, 2013, 200). All these things aim to protect Christianity from views that are considered contrary to it. Since then, religion in the Middle Ages had completely stopped all scientific activities and scientific experimentations, as it had once graced the Alexandrian library. In fact, religion in the Middle Ages had won the conflict over science. Science was nothing more than a religion (Ancilla Theologia) (Mustansyir and Munir, 2013, 128). By the end of the 13th century, Renaissance movements began in Italy and tried to break through the Middle Ages stagnation, which later gave birth to the Modern Age. Science was getting stronger and religious doctrine was getting weaker on the contrary (Hardiman, 2007, 8-9). Furthermore, in this Modern Age, the belief emerged that reason (science) can do everything and is more important than faith (religion). From here then comes the push for secularization, namely the separation between science and religious values, because religion is considered only an obstacle to mankind progress of mankind (Iqbal, xx). 
Quite a clear break with religion began to emerge through scientific discoveries of science. Nicolas Copernicus (1473-1543) revolutionized the traditional astronomical beliefs dominated by Aristotle's theory, which presupposes that the Earth is the center of the universe (Geocentric), which the Church believes for about a thousand years. Through research carried out by Copernicus, he found that the Sun was the center of the universe, and the Earth revolved around the Sun (Heliocentric). Furthermore, the genius astronomer Galileo-Galilei (1564-1642), through his discovery of a telescope in $1610 \mathrm{AD}$, proved the truth of Copernicus theory (Hardiman, 11-12). The current development of scientific activities could not be stopped by the strength of the Church's doctrine, along with Galileo, a scientist named Kepler (1571-1630), who supported Copernican theories. Then followed by Isac Newton (1642-1727), through the contribution of his thoughts, a scientific revolution made science a part of Western culture implemented (Syamsuddin, 54). The rate of development of science did not stop there. Science in the 2oth century was developing rapidly. In 1896, about 50,000 people were carrying out scientific traditions, and no more than 15,000 people who were responsible for the development of knowledge in the field of science. Sixty-six years laterin the 2oth century, at least one million people worked as scientific researchers. The total number including those working in the industry, government, and education, cannot be determined with accuracy, but more than two million people are involved in scientific research (Bernald, 1969, 714).

The development of science is in the number of people involved, but the character of science about society has changed. Science, in its growth, depends on industry and government. They even began to enter the world of institutions, teaching, and the military. Another obvious feature of this transformation is its geographic location. In 1896 all world science practice was centered in Germany, England, and France. The rest are in America and Europe and only a little in Asia and Africa. In 1954, when science in Germany, England, and France was highly developed, although uneven, its growth far exceeded science in America. Japan and India made fundamental contributions to world science development since the beginning of the 2oth century. China added a new dimension to the science building. This pattern then spread to other Asian countries such as Korea, Vietnam, and Indonesia (Bernald, 1969, 217). From the description above, it can be concluded that science in this modern age has developed in almost all parts of the world. Science in the twentieth century does not belong only to scientists in universities and research institutes but has entered the world of economy, society, government, and the military. Science greatly influences human life. Due to the Renaissance in the West, desecration of science given rise to a paradigm materialistic, impact value decadence in science and spiritual 
crisis in social life. Modern Western science has relinquished man's moral responsibility to nature. Society has a secular instinct to dominate nature, which arises as a consequence of the way humans perceive nature. In fact, in the present era of PostModernism, everything must be measured on empirical logical truth so that truth is measured through verification. Scientific activities and then remove the divine element in nature, both nuanced materialism and naturalism (Syamsuddin, 169).

Since the West's scientific revolution has separated the theological aspects and science on the creator's issues, religious studies are also approached and studied with a secular approach. It is so evident in modern science in the West that the separation between knowledge and faith, religion and science, and theology with all aspects of human life. This causes a lot of chaos as a result of the separation of humanity from humanity (Basuki, 2012, 55-56). Unconsciously, the various crises that occur in nature are a reflection of the current humanitarian crisis. Modern humans are no longer aware that they are part of nature but instead consider themselves separate entities from nature because no other creature in nature has. This is a form of crisis due to the absence of principle, both in intellectual and social realms (Wora, 2006, 1-2). In its development, the discourse on the relationship between religion and science has led to an increasingly sharp discussion on Islamic science issues that are different from Western science. Some scientists think that science has compatibility with the Qur'an, which is called the Bucailis group (Syamsuddin, 22). Some Islamic thinkers do not reject Western science and admit certain parts that are in line with Islamic science. Another Muslim view of Islamicity concerning science is that there is no conflict between Islam and modern science. Apart from the above efforts, there are also efforts to find common ground between Islam and science with various approaches. These approaches do not simply acknowledge Islamic science but also embrace all scientific disciplines to establish connections, build dialogue, correct each other, and provide mutual inputs (Baqir, 2005, 15). Tracing the importance of the traditional paths of Islamic science, modern Western science has developed in such a way as to adopt a philosophical foundation. This Islamic philosophical footing of modern science must be distinguished from the philosophical footing of Islamic science. The un-Islamic dimension of modern science is by no means limited to its underlying elements. Islamic elements include many of its practices, which are contrary to Islamic knowledge and scholarship ethics. It is for this reason that Muslims increasingly need to distinguish between Islamic and science (Bakar, 2008, 34).

Today, there are not many philosophical issues that matter more to the contemporary Islamic world than the relationship between Islam and modern 
science. Science in Islam is a unity between values of revelation and human creativity in developing the universe's potential. Islam has many doctrines that always direct all its adherents to realize their respective capabilities as much as possible in cultural aspects. Like all pure Islamic art, whether it is the forms of mosque architecture, poetry, to states and models of science development, all of them boil down to a form of devotion to divine values. Thus, science in Islam as a whole is a form of manifestation of the utilization of the universe's facilities, which indirectly comes from Allah (Nasr, 1997, 11). If we pay attention and analyze the descriptions mentioned above, the influence of science development in Indonesian society has become increasingly complex. Indonesian society will experience secularization, then the role of religion will be reduced in various planning policies in the social, economic, political, legal, etc. (Lubis, 2015, B8). Thus, the domination of science will shift the consideration of religion or spirituality. Indonesian society will be based on the emptiness of the soul, which will then make all basic considerations of lifebased on pragmatic attitudes. The pattern of social life becomes sectarian, egocentric, which results in no longer a bond of solidarity as a nation's citizen (Lubis, 2015, B8). Religion which has been degraded from its developmental life is more normative-ritual-ceremonial in order that it becomes a corner of life. Islam, which originally contributed to the civilization of West Lithuania and thus gave birth to European civilization's advancement, is also seen as bearing the error of this theocratic mindset. This became the historical burden borne by religious communities, especially Muslims (Lubis, 2015, B8).

Based on the explanations that the authors have described above, the author wishes to present an in-depth discussion of the relationship between religion and science as understood, articulated, and developed in Islam over the centuries. According to Islam, religion's essence is the acceptance of doctrine and the real practice of religion in all domains of human life and thought. This means that the creation of science by a Muslim must be significantly related to the Oneness of God. The most central basis in Islam is faith and charity. There will be no use for a believer, but he does nothing for the benefit of mankind in his life. Therefore, to answer the basic and central values in life, the Qur'an statesthat Allah will not send the Prophet Muhammad (with Islamic teachings) except to be a blessing for the entire universe (Lubis, 2015, B8). As contained in Q.S. al-Anbiya'/21: 107: "We have sent you 'O Prophet' only as a mercy for the whole world". The word grace confirms that religious treatises' arrival is not at all to make human life difficult (haraj). However, as a form of Allah's love, to better humanize humans with various conveniences. Because secular life will not be able to produce ideal goodness for humans and will instead bring life to a very despicable degree. Therefore, humans must be returned to their main 
mission, which is to use rationality to improve their lives optimally. But the use of that rationality must be guided by Divine values (Lubis, 2015, B8). However, this cannot be realized automatically when rationality and religiosity do not redefine their respective existence. Rationality must be used genuinely in order to produce dynamism, creativity, and innovation because that is what modern life demands. Thus, religion is a teaching that has absolute truth but must remain flexible in providing answers to various human life changes (Lubis, 2015, B8).

\section{Philosophy of Science}

In discussing the Islamic response to various global crises brought about by modern Western sciences, the views of most or many Muslims are determined by the principles that give rise to these crises. The leading cause of this philosophical problem is the ignorance of Muslims of their scientific heritage, which has been reduced in practices. Moving consciously or unconsciously of the assumptions of modern Western science, Islamic science is also understood as a primitive form of modern Western science and its predecessors, the Islamic character, along with all moral and spiritual values inherent in its methodology, bypassing and cutting. The reference points in determining the nature of Islamic science arise from "science" defined by modern Western science, not from "Islam" defined by its own integral and unifying principles, namely the principle of tawhid or the unity of Allah.

The process and scientific results in any science are largely determined by the underlying philosophical foundation, which provides a framework, direct, and determines the nature of the science it produces. This philosophical foundation is a theoretical framework, scientific paradigm, and basic assumptions. These three things are commonly called, in a sense, the philosophical basis that underlies scientific building and scientific activity in general. These three philosophical foundations' workings may not necessarily be demonstrated in a practical area, but they clearly determine the nature of the resulting knowledge. In the history of science development, these three things have a relationship not only historically but also systematically. It is called this because a certain paradigm is born based on certain basic assumptions, so a certain theory works not outside the realm of its paradigm.

All branches of science (natural sciences, social sciences, and humanities) are largely determined by the underlying theoretical framework, which has a more general, abstract, and philosophical area. Each theory has a framework commonly called a methodology so that each theory has methodological consequences. Different theories will have different methodologies. In scientific building, the methodology is a logical and objective aspect that allows scientific 
findings to be accepted (or rejected) rationally and objectively. That is why methodology is often interpreted as a logic of discovery. That way, the methodology is different from the method, which means process and procedure. The difference is that the former is philosophical, while the latter is technical. In scientific activities, although the two cannot be separated, they still have their own areas.

In an effort to find and formulate the philosophical dimensions of science from the perspective of Islamic thought, it is necessary to examine the structure of the two and then connect the basic elements into the two structures between one another. First, the religious structure of Islam, according to a hadith of the Prophet, Islam as a religion consists of three divisions, Islam, iman, and ihsan. The nature of each dimension can be seen from its linguistic and religious content. Islam refers to various acts of submission and submission to the divine will, God's laws in Islam, or morals that determine the hierarchy of values of all human actions and goals. Faith refers to all fundamental truths and realities that must be believed or known, more precisely to all divine and cosmic realities and their equivalents in the human universe. This is the domain of theology, cosmology, and psychology. Ihsan is none other than the practice of Islam and the manifestation of faith at its best (Bakar, $5^{1}$ ).

By itself, Ihsan is related to one's internalization or appreciation of Islam and faith, the first in the sense of realizing all spiritual and moral policies or virtues which are essential values of Sharia, and the latter in the sense of gaining knowledge of all the relationships or the nature of everything something. Second. The structure of science as a branch of knowledge and intellectual activity. In general, scientists agree that science is structurally divided into four basic components. The first component is a well-formulated subject or object of study related to accumulative knowledge in the form of various concepts, data, theories, and laws, as well as relationships. logical that lies between them. This collection of knowledge is the main content of science.

The second component consists of various basic assumptions that serve as the epistemological foundation of the science concerned. These basic assumptions are related to the nature and nature of the object of study and its ontological status. The whole truth has been assumed in this science, but may also be established in other science which is more fundamental and conference. The third component relates to the study methods used in this science. Muslim scholars and scientists are generally guided by the principle that the study method varies according to the nature and object of study. No single method is the same for all science. The fourth component relates to the goals that science is trying to achieve. The main goal of science is to find aspects of reality related to various objects of study. To obtain perfect knowledge of the domain of reality 
with scientific conviction and expertise ('ilm al-yaqin) (Bakar, 53).

While attempting to harmonize the four structures of science with Islam, let us first discuss the components of the second basic structure:basic assumptions or basic principles. Based on nature and epistemological status, the basic assumptions of science adopted by a certain scientific group may not fall into essential knowledge or dubious truths. In the opinions of Muslim philosophers of science, all basic assumptions can be reduced to the following four categories: a) Categories of various views or beliefs that are perceived; b) Categories of generally accepted views or beliefs; c) Categories of sensory knowledge or empirical data based on sense perception; and d) Categories of intellectual principles that are accepted intuitively (Bakar, $\left.5^{8}\right)$.

In Muslim philosophers' opinion, it is the basic assumptions of the "fourth" category that have ultimate truth and are very convincing. Therefore, it is entirely acceptable. Thus, only the truth of various basic rational assumptions based on intuition and logic can build a science's perfection. Whereas the first, second, and third categories of the basic assumptions mentioned above can be the nature of the belief that it can be right and can be wrong. Therefore, it needs to be scrutinized and checked to ensure that they do not conflict with Islamic doctrine. What is clearer is that the basic assumptions derived from sensory and empirically are more relevant to empirical sciences such as physics and chemistry. However, in the case of sciences whose approach involves subject matters such as elements of belief, conjecture, and a variety of more subjective views, the use of empirical assumptions alone is very inadequate. The necessary assumptions must be formulated based on a combination of empirical and rational knowledge.

Its main role is to provide and supply us with rational doctrines that can be more scientifically justified to serve as the basic assumptions of various science kinds. Cosmological doctrines are most needed in building the foundation and foundation of sciences such as physics and biology. The basic assumptions of science in life must be based on various conceptions such as soul and life relating to all living things. The importance of a scientific spirit illuminated by the light of religion in pursuing various sciences or sciences, including religion and philosophy, Muslim scientists are more sensitive to the need for a comprehensive view of knowledge. Their awareness of the interconnectedness and unity of all knowledge often has important consequences and impacts on their search for science's basic assumptions. The result is a stronger and more resilient intellectual foundation for the sciences that Muslim scientists have developed.

It has been previously emphasized that Islam has ethical and moral dimensions that must be identified with Sharia teachings. Likewise, the domain 
of science application is also a concern and concern for ethics. What matters is the cultural assessment and appreciation of science, science as a cultural institution, and the social context needed to maintain and advance science. Based on the description and explanation above, it can be emphasized that in formulating a conference relationship between Islam and science, science's ethical and societal dimensions must be linked with Sharia. In Islam, Sharia is the main source of its value system. Thus, the applications of science in Muslim society and culture must be guided by the value hierarchy of human actions and goals, according to sharia. In this value system, every human action falls into one of the following five categories: Obligatory, Sunnah, Haram, Makruh, Mubah. What is clear is that in the domain of science and technology applications, in modern times, this is mostly done by non-Muslims. In discussing various issues such as cultural appreciation of science and the social context in developing and advancing science, it must be extracted from Islamic teachings about science or science's social dimensions. To revive the Islamic scientific tradition in the contemporary world or create science about the universe that is both new and traditional, one of the main problems that require special attention and needs to be addressed and resolved thoroughly is methodology. There are fundamental differences between science's methodological conceptions in Islam or all other traditional civilizations. Their general opinion says that modern science was created using a methodology course known as the scientific method.

The idea that only one type of science about nature is possible, through the use of the Scientific Method, greatly influences the whole perspective of society regarding pre-modern sciences, including Islamic science. The scientific method's level of the application becomes a universal measuring tool for the scientific community in determining the degree of scientific creativity and the "purity" of pre-modern thought. The idea that only one methodology was responsible for creating science has been dispelled by many works on the method of science published during the last decade. On the contrary, the notion of methodological plurality has now received general recognition among historians and philosophers of contemporary science. Some of them have expanded it to accept Scripture as an inseparable component of this plurality of methodologies. Likewise, many professional scientists, especially physicists such as Capra, have turned to Eastern doctrines in the hope of finding solutions to some of the dilemmas and problems encountered at the frontiers of modern physics. The methodology of science in Islam is based on an epistemology fundamentally different from the dominant epistemology of modern science. In the case of the Islamic science paradigm, which is based on unity (tawhid). It does have an integrated and coherent view of the meaning of the plurality of 
methodologies. The methodologies in Islamic science derive from the al-Qur'an about reality and its position in that reality. The methods in Islamic science are not mutually contradictory. Instead, they are complementary ways of realizing Islamic science's ultimate goal, namely the Unity of Nature, whose goal itself comes from two sources of Revelation and Intellectual Intuition. Methodological principles in Islamic science are concerned with the essential relationship between the hierarchy of human knowledge and the universe's hierarchy and the principles governing that relationship.

In the history of Islamic intellectuals, we have inherited a large amount of literature that discusses scientific methodology, several scientific methodologies that are considered equally valid, namely, tajribi, burhani, 'irfani, and bayani.

1. Tajribi methodology

Tajribi means experiment, so the tajribi method is the same as the "experiment method". The experimental method was actually practiced in the early days of the Islamic scientific awakening of the ninth and tenth centuries. Research/experiments in the physical fields of material objects need to be carried out in specific ways so that the research and observations carried out can be as close to the truth as possible. In the Islamic scientific tradition, the observation of physical objects is carried out at two levels. First, the theoretical level, Muslim scientists carefully and critically study scientific works from certain physics fields, such as Astronomy, medicine, etc. Second, on a practical level, Muslim scholars carry out various experiments to prove right or wrong and reject certain theories.

2. The Burhani Method

The object of science in the Islamic scientific tradition is not limited to physical objects, but also non-physical objects. As al-Ghazali said, our senses could not reach non-physical objects, so to examine non-physical objects, we certainly need knowledge other than the senses. In the Islamic intellectual tradition, what is meant by reason is a reason ('aql), because reason is capable of doing many things that the five senses are unable to do. In his famous book "Mishkat al-Anwar", al-Ghazali provides interesting details about the advantages of reason over the senses. The burhani method is indispensable because just as sensory perception is not always accurate with the objects, it is researching, human reason is not always precise about the objects it perceives. The more so, these objects are non-sensory.

3. The 'Irfani method

In the Islamic scientific tradition, apart from the senses and reason, there are still other tools of knowledge that are recognized by Muslim scientists, namely called the heart (qalb) or in the language of philosophy called intuition. This intuitive method of knowledge became known as the irfani method, which 
could be used by sufis or Muslim theosophers (Muta'aliyah), such as Suhrawardi and Mulla Sadra. The Irfani method is also considered a legitimate scientific method, a lasting legacy of the Islamic scientific tradition.

4. Bayani Method

In addition to the world of the senses and reason as sources of knowledge, scholars $\mathrm{Mu}$ slim also believes al-Qur'an as a source of knowledge. As the universe is a source of vast knowledge, to understand it properly requires a method suitable for it. Muslim scholars call it the bayani method. Just as we need a phenomenological method to reveal the deeper the universe, a source understanding method is required in order to uncover a deeper reality than alQur'an (Kartanegara, 2006, 183-194). Various scientific findings touch on the same issue, but from different perspectives, with different emphasis and ending views. The terms used and the detailed descriptions that conceptualize human knowing behavior's dynamics may differ from one methodology to another but are entirely categorical in their views when emphasizing the hierarchical nature of human knowledge and the universe. Methodology in Islamic science must be rooted in the book revelation Islam and the revelation's spiritual tradition.

These methods have been formulated and applied in history with great success. This legacy is passed down to us today, even though many Muslims don't know about it. Indeed, there is a deep conceptual relationship between Islam's inner dimension, the depth and breadth of Muslim scientific thought, and the natural sciences embodied in Islamic civilization. As defined by Nasr, Attas, and others, Islamic science's philosophical foundations derive from Islamic metaphysical principles. Just as Islamic revelation determined the social and artistic life of Islamic civilization. It also provides direction for understanding the natural environment and its scientific studies. The doctrine of tawhid, the essential Islamic teaching, affirms the unity of divine principles and is projected into natural science as the essential unity and interconnection of the natural order. Thus, the sciences can be defined as Islamic, insofar as they conform to and reflect the Islamic world's main principles (Peters and Iqbal, 2006, 126- 127).

The metaphysical view of traditional civilization regarding nature and the scientific study has been lost in modern science. The philosophical basis of which begins with the breaking of Western thought from its traditional teachings, the emergence of modern science is not solely due to fundamental advances in the scientific method, measurement, and calculation. On the contrary, it results from a fundamental change in man's view of the universe. This view is based on several premises (basic assumptions), five of the most important: First. A secular view of the universe, which does not give God's space in the natural structure. Second. The mechanistic picture of the world proposed 
by modern science understands the cosmos as an independent machine. Third. The hegemony of rationalism and empiricism over today's conceptions of nature. Fourth. The ontological separation of the knowing subject and the object of knowledge occurs. Fifth. The exploitation of the natural environment as a source of global strength and power (Peters and Iqbal, 2006, 129- 130).

Some of these things can be called the fundamental elements of the worldview. Thus,the Islamic worldview, as intended by al-Attas, from the perspective of the Philosophy of Science, is nothing but a theologicalmetaphysical basis or hardcore or central premise or transcendental idea in Islamic science. This distinguishes science based on Islam from science-based on other religions or science that is not based on religion, if any in the discourse of contemporary Islamic thought. In this way, the rejection, apriori, doubt, and pessimism towards the birth of Islamic science have been answered from the point of view of the philosophy of science. To emphasize again, that in the perspective of contemporary science philosophy, there are three models of scientific development. First, the development of science, which emphasizes the basis of scientific methodology. This is the contribution of Francis Bacon and positivism. For scientists who only recognize methods and theory as the philosophical basis of science, of course. They reject the sociological-historical side of science, let alone the theological-metaphysical side; secondly, the development of science emphasizes scientific methodology plus the sociohistorical basis. This is the merit of Thomas Kuhn. The recognition of this paradigm necessitates scientists to understand that science is also a human and social construction. And the third model, the development of science, also emphasizes the three elements of scientific philosophy, namely the basis of scientific methodology, the socio-historical basis, and metaphysical theology.

The development of science in the third model allows religion-based science such as Islamic Science to be scientific. In other words, belief and even the Islamic faith as the basis of the theological-metaphysical scientists have a clear position as an integral part of the science building. The scientific building or scientific activity, in general, is very much determined by the accuracy in the use of theory and, ultimately, methodology. The accuracy can be measured from the opening of new perspectives and broader perspectives of the theory. Thus, more supporting evidence is found, also measured by its robustness from the classification and refutation process. However, it does not ignore the scientific paradigm's sociological-historical aspects and the theological-metaphysical side of the basic assumptions. Thus, eventually these three models are an inseparable part of the building knowledge.

If the first is the logical basis and objectivity of science, then the second is the human aspect of science, then the third is the basis of belief, faith, and 
diversity of science. Based on these three important elements of the Philosophy of Science, Islamic science, which is understood as science based on the Islamic religion, is possible to become scientific. The new definition of Islamic Science as a scientific activity must be continued towards the "action" research program. In this way, Islamic Science will produce new findings, new theories, new methodologies, new contexts, and so on. Without that effort, the image of pseudoscience and Bucaillian justification will hardly be lost from the scientific building of Islamic Science. The religious awareness and scientific enthusiasm of Muslim scientists or scientists flow from their awareness of tawhid. The epistemological basis of Islamic science, rooted in the unity of truth, ensures that the most meaningful and meaningful is the ultimate truth, namely God's glory. There is no possibility for scientific truths related to the lower order of reality to deprive or even threaten the absolute truth. As is the case with various observational studies of nature, it cannot lead to a desacralized form of empiricism, rationalism, or the denial of anything beyond the senses. Versatility includes God and His presence in everything that exists implicitly in the concept of tawhid and also explicitly as it is contained in Q.S. al-Hadid/57: 3: "He is the First and the Last, the Most High and Most Near, ${ }^{1}$ and He has 'perfect knowledge of all things". Thus, the natural world and everything in it cannot be viewed and understood as something independent of Him. All-natural phenomena must be reflected as "signs" of their unique causes, according to Q.S. al-Fussilat/41: 53: "We will show them Our signs in the universe and within themselves until it becomes clear to them that this 'Quran' is the truth. Is it not enough that your Lord is a Witness over all things?".

This last verse of the Koran also describes how important the relationship between the Santis's soul or the scientist and the external objects he studies. "Objectivity" must be understood more than simply as a value-free means of empirical observation, as is the case in Western science. Rather, it is an exact match or conformity between a knowing subject and a known object. For "science "to effectively integrate its various discoveries in order of greater significance and human benefit, it must have a foothold in that science that relates first and foremost to the Supreme Being. In elaborating on the relationship between the human soul and the cosmos, it is often seen as a mirror image. Because they both reflect each other's images, the relationship between the human soul and nature is understood as something that resembles the relationship between subject and object. The human soul is a conscious subject that can make the entire universe its object. So close is the relationship between the human soul and the universe that the human soul and the world can be viewed as an organism with two faces.

In more religious language, this means that God created the world with the 
specific purpose of crowning His accomplishments with humans, the only being created in His image and capable of serving as His caliph. In the intellectual tradition, the highest objective of studying the universe is to understand human powers and abilities. By understanding objects, humans can simultaneously understand their abilities and potentials. We cannot study the natural world without understanding ourselves, and we cannot understand ourselves without understanding the wisdom inherent in the natural world. According to Muslim intellectuals, Almighty God creates intelligently, the stage of the actuality of creation closest to His highest and absolute simplicity, intelligence, and pure consciousness. In this consciousness depicted the universe and the human soul. This living intelligence is the instrument by which God plans, orders, orders, and determines all beings, and it is at the root of every subject and object.

This single reality is the principle of the universe and the conscious human soul. The human soul is a knowing and conscious subject who can make the entire universe and everything in it its object. However, he is usually blind to his potential and makes the soul's color not completely human. The soul needs to learn how to be human, and being human is not easy. Most of us have to be reminded by the prophets of what it means to be human. This separation of God's will or the world sacred is what contemporary Muslims should completely avoid. This is because frontal attacks and assaults on all basic beliefs and beliefs can be clearly recognized by themselves. Modern science's various benefits seem to be unproblematic, objective, and "value-free" are poisonous and harmful to the faith. Every domination of human existence or existence must be viewed and evaluated in relation to God and the Universe. Because God makes this world meaningful, this world would be reduced to a meaningless game without Him. In the steps, we understand the signs of God's power embedded in the substance of this mortal world. We, as humans, can get a glimpse of that afterlife. Science, whatever its name, must be guided by the principles of metaphysics; if it fails in this, we will deviate from the meaning of life. And at worst, the meaning of life and the physical conditions needed to continue life are destroyed. Human happiness is determined by the renewal of the intellect obtained when a person has reached the stage of his actual reason. Therefore, only science-based on tauhid values can achieve happiness. Meanwhile, science that assumes God's death in him is nothing but a form of human intellectual death. Ecological disasters are an inevitable consequence of physical and spiritual chaos. Nature and the human self are not two separate realities but two mutually exclusive sides.

\section{Conclusion}


In formulating the philosophical dimensions of Islamic science, it is necessary to examine the structure of both, First. Islam's religious structure, Islam, as religion consists of three dimensions, Islam, Iman, and Ihsan. Second. Science is structurally divided into four basic components: well-formulated subject matter (object of study), fundamental assumptions that serve as the epistemological foundation of the science concerned, the study methodology used in the science, and the objectives trying to achieve by that science. When aligning the four structures of science with Islam, we first discuss its basic assumptions that arebased on nature and epistemological status. Basic assumptions can be reduced to four categories: categories of various views or beliefs that are generally accepted, types of various opinions or beliefs that are generally accepted, categories of sensory knowledge or empirical data based on sensory perceptions, categories of intellectual principles accepted intuitively. In this case, it is the basic assumptions of the "fourth" category, which have intrinsic and convincing truth. The truths of various are based on intuition and logic that can build the perfection of science. Methods in Islamic science derive from Revelation and Intellectual Intuition. Islamic scientific methodology is considered equally valid, such as tajribi, burhani, irfani, and bayani. The doctrine of tawhid emphasizes the unity of Divine principles, which are projected into the field of natural science as an essential unity of the natural order. Science can be defined as Islamic, which reflects the Islamic world view's main principles.

\section{References}

Bakar, Osman, 2008. Tawhid and Science; Islamic Perspectives on Religion and Science, terjemah Yuliani Liputo dan M.S. Nasrulloh, Bandung: Pustaka Hidayah.

Baqir, Zainal Abidin, 2005. Integrasi Ilmu dan Agama, Interpretasi dan Aksi, Bandung: Mizan.

Basuki, A. Singgih, 2012. Agama Ideal; Perspektif Perenial, Yogyakarta: Gress Publishing.

Bernald, J. D., 1069. Science in History, 3, Cambridge: M.I.T. Press.

Departemen Agama RI, 2005. al-Qur'an dan Terjemahannya, Bandung: PT Syaamil Cipta Media.

Hadiwijono, Harun, 1980. Sari Sejarah Filsafat Barat I, Yogyakarta: Kanisius.

Hardiman, F. Budi, 2007. Filsafat Modern, Dari Machiavelli sampai Nietzsche, Jakarata: Gramedia.

Iqbal, Muhammad, 2011. Ibn Rusyd \& Averroisme, Pemberontakan Terhadap Agama, Bandung: Citapustaka Media Perintis.

Kartanegara, Mulyadhi, 2006. Reaktualisasi Tradisi Ilmiah Islam, Jakarta: Baitul 
Ihsan.

Lubis, M. Ridwan, 2015. "Humanisme Teosentris", Harian Waspada, 27 November.

Madjid, Nurcholish, 200o. Islam Doktrin dan Peradaban: Sebuah Telaah Kritis tentang Masalah Keimanan, Kemanusiaan, dan Kemoderenan, Jakarta: Paramadina.

Mayer, Frederick, 1950. A History Of Acient \& Medieval Philosophy, New York: American Book Company.

Mustansyir, Rizal dan Misnal Munir, 2013. Filsafat Ilmu, Yogyakarta: Pustaka Pelajar.

Nasr, Seyyed Hossain, 1997. Sains dan Peradaban di Dalam Islam, Bandung: Penerbit Pustaka.

Peters, Ted dan Muzaffar Iqbal, 20o6. God, Life, and The Cosmos: Christian and Islamic Perspectives, terjemah Ahsin Muhammad dan Munir A. Mu'in, Bandung: Mizan.

Rahman, Maskyur Arif, 2013. Buku Pintar Sejarah Filsafat Barat, Yogyakarta: IRCiSoD.

Syamsuddin, Ach. Maimun, 2012. Integrasi Multidimensi Agama dan Sains; Analisis Sains Islam Naquib Al-Attas dan Mehdi Golshani, Yogyakarta: IRCiSod.

Tafsir, Ahmad, 2009. Filsafat Umum: Akal dan Hati Sejak Thales Sampai Capra, Bandung: PT. Remaja Rosdakarya.

Wora, Emanuel, 2006. Perenialisme; Kritik atas Modernisme dan Postmodernisme, Yogyakarta: Kanisius. 